\title{
Krisztina Rábai
}

(iD) https://orcid.org/0000-0001-7758-6925

Department of Auxiliaries to the Study of History, Faculty of Arts, University of Szeged

\section{Jagellonian Ledgers as Sources for Watermark Research and Paper History Studies: The First Papermills of East-Central Europe ${ }^{1}$}

\section{Preliminaries}

This study's purpose is to give an overview of my five months of research in Poland in 2019, supported by the Polish Institute of Advanced Studies (PIASt). Furthermore - by sketching its topic and results - I aim to encourage a scientific discussion and draw the attention of scholars who are interested in paper history and watermark research. ${ }^{2}$

Paper was a revolutionary invention, which altered the human attitude to the written word forever. The art of papermaking and its spreading all over Europe had a significant impact on various fields of human history. While the importance of Gutenberg's invention is evident, undoubtedly it could not achieve such a huge success without paper; nevertheless, the medium of writing and

${ }^{1}$ In this article, I use the term "East-Central Europe" according to the historical literature, as it was defined by Oskar Halecki.

${ }^{2}$ Here, I would like to express my gratitude to all of my colleagues and friends (especially from the Department of Historical Atlas, Institute of History, Polish Academy of Sciences; lead by prof. Marek Słoń) who helped me with my research. I could not write this article without the support of PIASt grant (2019); my special thanks go to the director, prof. Przemysław Urbańczyk and all the fellows who encouraged my work during the 5 months. I cannot express how very grateful I am to Marta Walenta (PIASt) and Dr Wiesława Duży for all their help and support. 
printing was in the shadow of the research. Even nowadays, Gutenberg's name is well known, unlike Fabriano (the cradle of papermaking sank into oblivion). There are many unsolved questions concerning producing, trading, and using paper even in the early stage of printing.

My research project under the title "The Usage and Acquisition of Paper in the Jagiellonian Courts (1492-1507)" has been related to the fields of historical source edition, paper history, and watermark studies, in connection with a well-defined group of sources, the royal court accounts of the third generation of Jagiellonians (Wladyslaw, John Albert, Alexander, Sigismund) issued between 1492 and 1507, between the coronation of John Albert and the coronation of Sigismund. Both the main and auxiliary volumes document the daily income and expenditure of princely and royal courts. The registers concerned are mostly preserved in Warsaw in the Central Archives of Historical Records (Archiwum Główne Akt Dawnych) among the archival material of the royal treasury (Archiwum Skarbu Koronnego) with other account books (Rachunki królewskie); there is only one exception, the account of Wladyslaw, the Bohemian-Hungarian king, which is in the collection of the National Széchényi Library in Budapest.

A significant part of the project was the investigation of material evidence, i.e. the analysis and comparison of watermarks visible on the paper of the accounts (altogether 20 volumes). ${ }^{3}$ The main questions to be answered were: where did the paper come from? Did the Jagiellonian courts use the same quality of paper from the same paper mill(s)? Was there a direct connection with a paper mill, with a merchant, or with a special trading group which was responsible for the satisfactory paper supply to these royal courts?

Textual information can also provide evidence of paper purchasing. Among the purposes of the project was the edition of one of John Albert's main accounts, ${ }^{4}$ which may provide some more information about purchasing and using paper in the royal court. Relying on the editions of the examined registers, ${ }^{5}$ paper research can obtain information about the quantity,

${ }^{3}$ The examined manuscripts (royal and princely ledgers) include: Archiwum Główne Akt Dawnych, Archiwum Skarbu Koronnego (hereinafter AGAD ASK) 1 No. 20-38; Országos Széchényi Könyvtár [National Széchényi Library in Hungary] (hereinafter OSZK) Cod. Lat. 411.

${ }^{4}$ Registrum extraditorum pro serenissimo domino Johanne Alberto rege Poloniae per Jacobum de Schidlowyecz vicethezaurarium. 1493-1497. AGAD ASK 1 No. 22. Unfortunately, the text of John Albert's ledger does not contain information concerning the paper.

${ }^{5}$ D. Antanavičius, R. Petrauskas: Lietuvos didžiojo kunigaikščio Aleksandro Jogailaičio dvaro saskaitu knygos (1494-1504). Vilnius 2007; P. KozÁK: Účty dvora prince Zikmunda Jagellonského, vévody hlohovského a opavského, nejvyššiho hejtmana Slezska a Lužic, z let (1493) 1500-1507: Kritická edice pramene. Rationes curiae Sigismundi Iagellonici, ducis Glogoviensis et Opaviensis, Silesiae et Lusatiarum summi capitanei, de annis (1493) 15001507: Editio critica. Praha 2014; K. RÁBAI: Jagelló Zsigmond udvarának számadáskönyve 
the quality, and the usage of the paper. The first paper mills on the territories controlled by the members of the Jagiellonian dynasty were established at the end of the $15^{\text {th }}$ and the beginning of the $16^{\text {th }}$ centuries (Wrockaw between 1475 and 1490, Świdnica cc. 1490/1499, Prądnik Czerwony 1491, Nysa 1496, Racibórz 1497, Zbraslav 1499, Mogiła cc. 1500, Opava between 1501 and 1506, Trutnov before 1505, Olomouc 1505). Is it possible to detect the usage of local paper products via either material evidence or textual information? ${ }^{6}$

\section{Archival Sources and Watermark Images}

As the number of medieval texts dealing with paper in any aspect (e.g. technological background of producing, establishing of papermills, etc.) is quite small, if we want to find out how the paper "industry" and paper trade started, developed, and worked in medieval and early modern Europe (i.e. in the "Jagiellonian Kingdoms"), we have to examine not only the content of texts, but also the medium of writing itself. The elaboration of archival material is quite diverse, but generally one can say that systematic investigation and registration of watermarks have not reached the level of necessity yet. Not only archival catalogues but also catalogues of other collections usually fail to pay attention to the medium of writing/printing/painting.

Analysis and comparison of the external features of charters issued in different territories within the same period could reveal many elements. Nevertheless, codices and books like ledgers could provide a much adequate foundation for watermark research as a large amount of paper from the same papermill was used to prepare these volumes. The detailed analysis can also give us information about the usage of the pair of moulds, make possible the identification of these moulds, and make detectable the alteration of these objects

(1504-1507): The Court Account Book of Sigismund Jagiellon (1504-1507). Szeged 2014; P. KozÁK, K. RÁBAI: Mezi periferii a centrem jagellonského světa: Registrum dvořanů knižete a krále Zikmunda I. Jagellonského z let 1493-1510. Opava 2015; P. KozÁK: Úč́ty budinského dvora krále Vladislava II. Jagellonského (1494-1495). Praha 2019. For earlier editions of these ledgers (by Engel, Pawiński, Divéky) see the bibliography of the modern editions.

${ }^{6}$ The summary of the project is also available on the webpage of PIASt (http://www.piast .pan.pl $/$ index.php?option $=$ com_content\&view $=$ article $\&$ id $=480:$ krisztina-rabai\&catid $=73 \&$ Item id=306\&lang $=$ en). 
during the period in which they were used. ${ }^{7}$ To achieve reliable results, we also need a significant amount of paper, in comparable quantity and quality.

Nowadays, thanks to the rise of supportive technical background, new digital tools and techniques for visualising (non-invasive imaging techniques) are involved in filigranology, improving the quality of watermark images. ${ }^{8}$ The most significant collections, such as Briquet's or Piccard's works, were digitised $^{9}$; furthermore, many public institutes made their watermarks available through different databases. Bernstein — the Memory of Paper portal attempts to summarise and share all the information concerning watermark research with a comprehensive bibliography, a catalogue, and freely available tools helpful for watermark imaging and analysis.

Among the examination of the external characteristics of archival material, what is the most difficult is the study of watermarks, as many factors affect the visibility of these marks (recent condition of the material, size of the sheet and place of the watermark, handwritten or printed text on the paper, the ingredients used to prepare the ink, etc.). Their registration is also a difficult task, which has been eased only recently by a well-developed and internationally accepted standard. The printed catalogues, articles, scientific works, and digital images of watermarks represent a wide variety of quality and quantity. Thanks to the work of the International Association of Paper Historians (IPH),

${ }^{7}$ For the best recent summary of watermark research, see N. HARRIs: Paper and Watermarks as Bibliographical Evidence. Lyon 2017. The detailed explanation of watermarks, moulds, and other essential technical knowledge for understanding the process of papermaking is available online. To help the work of watermark studies, in addition, an extended bibliography is also available.

${ }^{8}$ F.G. France, M.B. Tотн: Spectral Imaging for Revealing and Preserving World Cultural Heritage. In: 19th European Signal Processing Conference. Barcelona 2011, pp. 14501454; V. Karnaukohov: Methods and Tools for Watermark Digital Processing, Archiving and Dating. In: Eikonopoiia, Digital Imaging of Ancient Textual Heritage, Proceedings of the International Conference Helsinki 28-29 November 2010. Helsinki 2011, pp. 143-159; Z. ZHang, U. Ewert, T.D. Barret, L.J. Bond: Paper Watermark Imaging Using Electron and Low Energy X-ray Radiography. "AIP Conference Proceedings" 2019, Vol. 2102, No. 1, pp. 1-9. Concerning the most recent projects and developments on the digital field of watermark research, see the papers presented by Silvia Hufnagel, Annelies van Hoesel, Giles Bergel, Elena Ukhanova, Ilaria Pastrolin on the $5^{\text {th }}$ International Conference on Watermarks in Digital Collections (available through Bernstein - the Memory of Paper portal, https://bernstein.oeaw.ac.at/twiki/ bin/view/Main/Conference_Cork20191016.html [accessed: 29 $9^{\text {th }}$ November 2019]).

${ }^{9}$ Ch.-M. BRIQuet: Les filigranes: dictionnaire historique des marques du papier des leur apparition vers 1282 jusqu'en 1600. Geneva 1907; Briquet Online, http://www.ksbm.oeaw .ac.at/sscripts/php/BR.php [accessed: 17 $7^{\text {th }}$ September 2019] (hereinafter Briquet); Piccard Online, http://www.piccard-online.de/start.php [accessed: 17 $7^{\text {th }}$ September 2019] (hereinafter Piccard). Piccard's collection was published in 25 volumes until 1997, dividing the watermarks into 17 groups (Ochsenkopf, Krone, Turm, etc.). Piccard's work, the elaboration of its watermarks, and the connecting scientific literature are available online: https://www.piccard-online .de/ [accessed: 17 $7^{\text {th }}$ September 2019]. 
the International Standard for the Registration of Paper with or without Watermarks has been available since the $1990 \mathrm{~s} .{ }^{10}$ However, on the one hand, this is a recommended and not obligatory system for new watermark databases, and, on the other, the already existing catalogues did not apply these rules (because they had not existed).

These characteristics make the comparison and identification of watermarks difficult, sometimes even impossible. During my work with the Jagiellonian ledgers, the most reliable databases (WZMA, WIZIS) ${ }^{11}$ and the printed Polish catalogues from the first collector, Joachim Lelewel in the $19^{\text {th }}$ century, through the work of Ptaśnik, Piekosińsky, Piekarski, Budka, Badecki, Maleczyńska, Siniarska-Czaplicka, and Dąbrowski, ${ }^{12}$ contributed to the identification of watermarks.

\title{
The Identification of Watermarks Visible on Royal Ledgers
}

\author{
Watermarks in the mentioned manuscripts are wire watermarks on rag
} paper.

${ }^{10}$ International Association of Paper Historians (IPH): International Standard for the Registration of Paper with or without Watermarks, English Version 2.0, 1997, http://www.paper -history.org/standard.htm [accessed: 17 ${ }^{\text {th }}$ September 2019].

${ }_{11}$ WZMA - Wasserzeichen des Mittelalters. Österreichische Akademie der Wissenschaften, http://www.wzma.at/ [accessed: 17 ${ }^{\text {th }}$ September 2019]; WIZIS - WasserzeichenInformationssystem. Deutsche Forschungsgemeinschaft, 2012, www.wasserzeichen-online.de [accessed: $17^{\text {th }}$ September 2019].

12 Joachima Lelewela bibljograficznych ksiag dwoje, w których rozebrane i pomnożone zostaty dwa dzieła Jerzego Samuela Bandtke: Historja drukarń krakowskich — tudzież Historja Bibljoteki Uniw. Jagiell. w Krakowie, a przydany Katalog inkunabulow polskich. Vol. 2. Wilno 1826. Tablica XVII-XVIII; Papiernie w Polsce XVI wieku: prace Franciszka Piekosińskiego, Jana Ptaśnika, Kazimierza Piekarskiego. Ed. W. BudKa. Wrocław 1971; J. PTAśnıK: Papiernie w Polsce XVI wieku. Kraków 1920; K. BADECKI: Znaki wodne w ksiegach archiwum miasta Lwowa 1382-1600 r. Lwów 1928; S. ŻUrowski: Znaki wodne papiernictwa wielkopolskiego XVI-XIX w. Poznań 1965; J. Siniarska-CzaPlicka: Katalog filigranów czerpalni Rzeczypospolitej zebrany z papieru druków tłoczonych w latach 1500-1800. Łódź 1983; J. SINIARSKA-CZAPLICKA: Filigrany papierni położonych na obszarze Rzeczypospolitej Polskiej od początku XVI do połowy XVIII wieku. Wrocław 1969; J. DĄBrowski, J. SiniarsKa-CzAPlickA: Rękodzieło papiernicze. Warszawa 1991; J. DĄBRowski: Paper Manufacture in Central and Eastern Europe before the Introduction of Paper-making Machines. Łódź 2008, http://www .paperhistory.org/dabro.pdf [accessed: $17^{\text {th }}$ September 2019]. 
The most important tool of papermaking is the mould [...] in Europe [...]. The mould was made from a wooden frame [...] on which a brass wire sieve was stretched $[\ldots]$. The sieve was formed by the widely spaced chain lines and the more narrowly spaced laid lines. To this construction were attached (usually parallel to the chain lines) various designs or sometimes letters and numbers, made of bent copper wire, with the purpose of identifying the paper mill. After vatting, as water trickles out, the fibres bind together somewhat less densely over the wires, so the paper becomes less dense there. By holding the paper against the light, the impression of the sieve is visible as a more transparent pattern, while the designs $[\ldots]$ form watermarks [...]. Symbols identifying the paper mill, or perhaps the coat of arms of its owner, however they could also be used to identify paper quality. ${ }^{13}$

There are various, mostly quite expensive, techniques of reproducing watermarks. For the recent project, a quick, relatively low-cost process produced a good quality of image. It is the back-lighting technique, which requires an electroluminescent slim light sheet or any other light-source place behind the paper without causing any damage. The light provides homogeneous illumination behind the watermark making the impression of the sieve and the wire-mark visible and possible to catch the image by the help of a digital camera. Besides the quality and low cost, this method does not imperil the original material.

Taking photos of the watermarks, measuring them, reconstructing the structure of the moulds, and identifying the relating pairs of moulds were the most important parts of the work. Without going into unnecessary details, ${ }^{14}$ the watermarks of the examined royal and princely ledgers can be divided into sixteen main groups. Eight of them represent different types of bull's head marks. The rest demonstrate a clerical hat, scales, a crown, a crossbow, a patriarchal cross, a circle with a star, letter "W" with a crown and a fishtail, and a boar.

The overall result is that those investigated manuscripts which belonged to the courts of Wladyslaw, John Albert, and Alexander were made from goodquality Italian paper; within one volume usually one type of watermark was used (maximum two types). Prince Sigismund's accounts - two main volumes and one auxiliary volume - obviously differ from his brothers' concerning the number of folios, the variety of watermarks, and the origin of the paper.

13 G. BoRsA: Kalauz a régi nyomtatványokhoz: A régi nyomtatványok fogalma, anyaga, mérete és terjedelme. Budapest 2003, pp. 20-21; I. BoGDÁN: Vizjelek és vízjelkutatás. "Levéltári Híradó" 1956, Vol. 8, p. 28.

${ }^{14}$ More information with the table of watermarks will be published in K. RÁBAI: The Usage and Acquisition of Paper in the Jagiellonian Courts, 1490-1507. In: The Paper Trade in Early Modern Europe. Practices, Materials, Networks. Eds. D. Bellingradt, A. Reynolds. Leiden-Boston 2021 (forthcoming). 
These are the most robust volumes among the examined material, with over 300 folios per volume. ${ }^{15}$ The huge number of sheets does not surprise if we compare the length and accuracy of the sentences with the aforementioned royal ledgers, which are rather laconic.

\section{Textual Information about the Paper}

Albeit these first-rate sources (picturing the colourful image of everyday life, giving us information about culture, entertainment, clothes, victuals, political events, commercialism, prices, and many other relevant data) were examined from many different aspects, ${ }^{16}$ no particular attention was paid to purchasing and using of paper. Where did they buy the paper from? Regarding the peculiarities of the examined ledgers, only Sigismund's accounts provide adequate textual information concerning the paper. The prince and his court frequently travelled in the studied period; furthermore, Sigismund also had a significant territory under his control as he was the Duke of Głogów (1499-) and Opava (1501—), the governor of Silesia and Lusatia (1504-). He often visited the region of Silesia and the Polish royal residence in Kraków, where the first papermills were already working and producing paper for the local and possibly for the neighbourhood markets as well.

Based on the text of these ledgers, inevitably the court purchased paper in the important cities and towns, where it spent the most time. Although the

${ }^{15}$ For the auxiliary account with the name of courtiers and salaries paid for them during the years, see AGAD ASK 1 No. 21 (the manuscript contains 329 folios); the first main account preserved was written between 1500-1504: AGAD ASK 1 No. 29 (the manuscript contains 388 folios), the second main account was issued between 1504 and 1507: AGAD ASK 1 No. 33 (the manuscript contains 393 folios).

${ }^{16}$ A couple of examples: A. NalewajeK: Na królewskim dworze Jana Olbrachta. "Roczniki Humanistyczne" 2011, Vol. 49, pp. 41-80; J. SkiBniewska: Dwór królewski Aleksandra Jagiellończyka w latach 1501-1506. Lublin 2015; Z. HoroGSZEGI: Egy számadáskönyv kultúrtörténeti vonatkozásai. In: Középkortörténeti tanulmányok. Az 5. Medievisztikai PhD-konferencia (Szeged, 2007. június 7-8.) elöadásai. Ed. M. Halmágyi. Szeged 2007, pp. 33-40; K. RÁBAI: Jagelló Zsigmond számadásainak orvostörténeti tanulságai. In: Középkortörténeti tanulmányok..., pp. 133-140; P. KozÁK: Meals and Beverages on Prince Sigismund's Dining Table: Some Remarks on the Possibilities of Knowing the Diet of the Jagiellonian Rulers at the Turn of the $15 t^{\text {h }}$ and $16^{\text {th }}$ Centuries. "Perspektywy Kultury" 2016, Vol. 15, pp. $61-107$. 
princely household usually purchased a higher quantity of paper in bigger cities such as Kraków or Buda for its journeys (ad viam), it would appear that this commercial product was also available in regional centres (Opava, Głogów, Wrocław, Nitra, Szeged) and smaller towns (Kesztölc, Grodków, Świdnica). The places where the paper was purchased indicate an extensive network of commercial paper producers. More than a hundred sentences refer to paper purchase and shed light upon the use of paper between 1500 and 1507. One can say that paper was used nearly exclusively for writing purposes, requiring good quality of paper, which in this time was not exclusively produced in Italy or Western Europe.

Predominately paper was bought for the treasury (ad thesaurum), 75 times over 6 years. Maybe on some of the 17 occasions when the reason/purpose of purchasing is not given, treasury expenses were also involved. Frequently mentioned (14 times) is the aim of writing a letter. The demand to purchase highquality paper was rarely emphasised. ${ }^{17}$ Quantities steadily increased during the years. While in 1500 the amount of purchased paper was 6.5 librae (pound), in 1506 the amount was nearly four times as big, that is, 24.5 librae. Occasionally, wrapping paper also appeared among the expenses. ${ }^{18}$

The purchase of paper, for use in ledgers, the payment for the labour of interlacing this paper into ledgers, and the buying of pre-made blank ledgers were documented in the main account. On one occasion, a registrum was bought for travelling in which sums were recorded before their entry into the main account book (this practice can explain the contradiction - described below - in the case of the courtiers' register). Other notes reflect money paid out as a fee for interlacing or binding papers into a new account book. ${ }^{19}$

17 "Item pro una resa papiri Italici pro scribendis litteris, quum est necessarium domino principi, quia talis raro invenire, dedi II florenos." AGAD ASK 1 No. 33, fol. 37verso (=v). This quantity of paper, especially for letter writing, was very large (1 ream), and also expensive (2 florins). The necessity of this particular transaction "because such [quality] could be gained rarely" is somewhat surprising, as the place of purchase is Kraków.

18 "Item pro I 1/2 libra papiri, ad involvendum czukarum et crocum pro via, dedi III grossos. [17. July 1504., Opava] [...] Item pro papiro simplici ad ligandum crocum dedi I grossum. [7 January 1506, Wrocław] [...] Item pro papiro ad involvendum skarlatum donatum a domino Czyolek dedi 1/2 grossum. [26 February 1506, Kraków]" AGAD ASK 1 No. 33, fol. 28recto(=r), $159 \mathrm{v}, 172 \mathrm{v}$.

19 "Item pro registro novo ad viam, in quo summe describuntur, antequam in regestrum summarum inscribuntur, dedi VIII grossos [...] Item eodem die pro papiro II1/2 libris ad ligandum in registrum summarum dedi $\mathrm{V}$ grossos [...] Item a labore eiusdem registri, dum papirum introligatum est, dedi III grossos [...] Item a ligatione papiri ad registrum, ubi summe scribi debebant, dedi III grossos [...] Item pro novo registro ad conscribendum equos curiensium dedi XX grossos." AGAD ASK 1 No. 33, fol. 77r, 302r, 222v, 168r. 


\section{Combining Textuality with Materiality}

As we have seen, most of the times, the text does not refer to the origin and quality of the paper. To figure out these significant elements, one has to analyse the preserved paper itself. Unfortunately, no systematic research was carried out on the letters and charters issued/written in the Jagiellonian courts; therefore, we only have sparse data about them.

The watermarks of the first preserved main account of prince Sigismund's household - documented the incomes and expenses between 1500 and $1504-$ prove the usage of paper from Italian papermills. In comparison with the royal ledgers, this volume contains more types of watermarks (4 main types).

In the chronological order, the next preserved ledger belonging to the prince as the register of courtiers. Judging by the watermarks, paper produced in Wrocław and Świdnica was frequently used. This local product was incorporated into the princely accounts from 1502 on. Although this auxiliary volume contains the first notes dated back to 1493, the structure of the manuscript, the slowly growing number of the courtiers, and other details indicate that the first notes between 1493 and 1500/1501 were copied into the manuscript around 1501/1502. ${ }^{20}$ By distinguishing the different hands and drawing up the list of courtiers - according to the chronological order when they were engaged in the service of the prince - one can see the time-layers of the manuscript. At the beginning, the scriptor registered the newcomer(s) on the top of the recto(s) and left approximately five blank pages for each of them (during the years filled with payments made for them). When sharp growth occurred in the number of courtiers (around the end of 1506 and the beginning of 1507), the scriptor used these blank pages to register them (filling the gap and causing the mess in chronology). ${ }^{21}$

20 The first courtier of Sigismund was Krzysztof Szydłowiecki, who received a regular payment from the prince's treasury since 1493. The next noble members joined the court (which included 8 courtiers) when Sigismund left Kraków and moved to Buda around 1498. Significant growth in the number of courtiers occurred in 1502 and 1506/1507 in line with the death of Sigismund's two brothers, John Albert and Alexander (whose courtiers were "inherited" by Sigismund). A. DivÉKy: Zsigmond lengyel herceg II. Ulászló udvarában. "Századok" 1914, Vol. 48, pp. 449—463, 562—576; P. KozÁк, K. RÁBAI: Mezi periferií a centrem jagellonského světa..., pp. LI-LXIII.

${ }^{21}$ The time-layers and the structure of the manuscript (the first number is the number of the folio [manuscript AGAD ASK 1 No. 21], the second is the page number in the edition P. KoZÁк, K. RÁBAI: Mezi periferii a centrem jagellonského světa...): year 1493/1498: 2r—p.2, 23rp.26, 28r-p.32, 33r-p.39, 38r-p.47, 43r-p.54, 49r-p.60, 55r-p.67; year 1501: $17 \mathrm{r}-\mathrm{p} .21$, $61 \mathrm{r}-\mathrm{p} .74,66 \mathrm{r}-\mathrm{p} .82,71 \mathrm{r}$-p.89, 75r-p.95, 157r-p.197; year 1502: 80r-p.100, 85r-p.104, 90r-p.112, 95r-p.117, 99r-p.124, 103r-p.130, 108r-p.136, 112r-p.142, 118r-p.149, 
The watermarks on the paper also strengthen this conclusion. The letter "W" with a crown on the top and a sort of fishtail under is known in the scientific literature as the sign of the papermill in Wrocław. One can find similar marks in the collection of Piccard, on the paper used by the royal members of the Jagiellonian dynasty between $1498-1504 .{ }^{22}$ The first 16 gatherings of the courtiers' account (193 folios) bear this watermark.

The rest of the volume shows a colourful variety of papers concerning their watermarks and their quality as well. These 14 gatherings count 137 folios. Fortunately, the main account preserved two precious sentences which shed light upon the circumstances. There are two records about the purchasing of paper for accounts (propter registra). On $6^{\text {th }}$ January 1507, "1 libra" of good quality of paper was bought in Mielnik for " 2 and a half groschen," and 3 days later in Łuków it was necessary to buy more paper ("1 libra" for "2 groschen") because many other courtiers had to be listed in the account. ${ }^{23}$ If we compare this information with the paper and the special chronological disorder of the auxiliary volume, these extra sheets of paper are clearly seen to be significant. Having run out of paper, the scriptor started to fill the gaps, previously left blank. ${ }^{24}$ As they were able to buy some paper in Mielnik and Łuków, some of the newcomers were registered on those sheets. In my opinion, these two "mixed gatherings" of bull's heads (with a cross and a serpent) watermarked papers could be purchased in Mielnik and/or Łuków. These gatherings contain some paper of evidently lower quality. The courtiers recorded on these pages and also on the $19^{\text {th }}$ and $20^{\text {th }}$ gatherings (with the crown watermark of Italian origin) joined Sigismund's court between the last days of December 1506 and the first weeks of January 1507 (they were former courtiers to Alexander, who died in 1506).

Italian paper can be detected as well as the product of the papermill in Świdnica, represented by good quality of paper with the typical boar watermark

$123 \mathrm{r}-\mathrm{p} .156,129 \mathrm{r}-\mathrm{p} .163,134 \mathrm{r}-\mathrm{p} .169,138 . \mathrm{r}-\mathrm{p} .173,141 \mathrm{r}-\mathrm{p} .178,146 \mathrm{r}-\mathrm{p} .183,150 \mathrm{r}-\mathrm{p} .187$, $153 \mathrm{r}$ - p.193, 162r-p.203, 167r-p.207, 171r-p.212; year 1503: 175r-p.217, 179r-p.223, 182r - p.226; year 1504: $163 \mathrm{r}$ - p.204; year 1505: $185 \mathrm{r}$ - p.230, 188r - p.234, year 1506: $192 \mathrm{r}$ p.238, 194r - p.241, 197r - p.244, 200r-p.246; year 1507 starting from: $203 \mathrm{r}$ - p.247.

22 Briquet 9164 (Legnica 1500); Piccard DE4620-PO-29851 (Kraków 1500); Piccard DE4620-PO-29852 (Sandomierz 1500); Piccard DE4620-PO-29854 (Legnica 1502); Piccard DE4620-PO-29856 (Toruń 1504).

23 "Item eodem die pro I libra papiri bona dedi II $1 / 2$ grossos propter registra... Item eodem die pro I libra papiri, quum alii curienses et multi conscribi debebantur, propter registra dedi II grossos." AGAD ASK 1 No. 33. fol. 244r, 245r. [6 $6^{\text {th }}$ and $9^{\text {th }}$ January 1507 , Mielnik and Łuków].

${ }^{24}$ See a few examples from the manuscript to have an idea about the filling of gaps (the first number is the number of the folio, the second is the page number in the edition P. KozÁk, K. RÁBAI: Mezi periferií a centrem jagellonského světa...) between December 1506 and January 1507: $12 \mathrm{r}-$ p.16, $14 \mathrm{v}-$ p.19, 44r-p.55. The year 1507 chronologically started on $203 \mathrm{r}$. 
of the mill. The design is rich in detail; the boar's mane, both ears, eye, mouth, tusk, spiralled tail, genitals, the arcs of its hind legs and forelegs, and cloven hooves are all clearly visible. This watermark/paper became very "popular" on the market, as we can find it among the papers of the second main accounts of the prince issued between 1504 and 1507, as well as in his other ledger (Regestrum quittantiarum regalium) starting from $1507 .{ }^{25}$ The search for finding the identical watermark in the albums and databases cited before was not successful. One can see similar signs — but dated nearly a decade later in Piccard's and in Briquet's collections. ${ }^{26}$

There are a few sheets whose origin is questionable: a couple of them marked with the patriarchal cross (this sign was used in Prądnik Czerwony but also can refer to the mills of the Upper Rhine region) ${ }^{27}$; two other with the bull's head - a very popular and widely used watermark — with a Latin cross and a serpent around. The last two examples, the two sheets of paper marked with bull's head, are clearly different from each other (most probably the two sheets were made on a pair of moulds) and from the remainder of such watermarks in the volume. While these two watermarks are similar to the Italian bull's head marks of the volume, there are noticeable differences in size and shape. Not only the mark but also the colour and the quality of these sheets differ from the other bull's head marked papers of the manuscript. All attempts to identify them have failed. One single sheet - most probably — preserved the fragment of Mogiła's watermark reflecting a bull's head with eyes above a crosier beneath a ring.

While searching for similar watermarks in the Polish literature, I came across an article describing an ecclesiastical tax register from the region of Świdnica (a list of incomes of the parish from tithing). The study - written by Joanna Ważyńska and Józef Dąbrowski — was based on the diploma work of Ważyńska, who restored the manuscript. They distinguished 38 different types of watermarks on the paper of the volumes. The register itself contains notes from 1471 until 1507, and according to Ważyńska, initially, there were small separate folders which were bound together after $1507 .{ }^{28}$

${ }^{25}$ The second main account contains a few sheets of boar marked paper concerning the years 1504, 1505, 1506. AGAD ASK 1 No. 33. Regestrum quittantiarum regalium (1507-1515) AGAD ASK 1 No. 38. The whole manuscript was written on paper bearing boar watermarks.

26 Piccard DE4620-PO-85553; Briquet 13574-13583.

27 Without the matching of the exact size and other details, the identity cannot be proved. Unfortunately, the available catalogues (reproducing this watermarks) do not give us these details.

28 J. WAŻYŃSKA, J. DĄBROWSKI: Średniowieczny ślaski rękopis kościelny cennym źródtem filigranów. "Przegląd Papierniczy" 1998, Vol. 54, pp. 403-406, 423-424. I would like to express my gratitude to Dr Karolina Puchała-Rojek, who gave her permission to study the manuscript (Rkp. 2381.), and also the diploma work of J. WAŻYŃSKA (Dokumentacja konserwatorska oprawnego kodeksu rękopiśmiennego „Rationes Frumentorum Parochialis [Schweidnitzensis] 
According to Dąbrowski, the boar watermark is unquestionably related to the papermill in Świdnica (more precisely Bystrzyca Górna, where the watermill was located). He suggested to date the beginning of papermaking to 1499 in this mill based on the date which is written on those specific sheets of Frumentorum Parochialis. The first boar watermarks (a less artistic form of the aforedescribed mark) appeared on the paper bearing the notes of the year 1499 . $\mathrm{He}$ also faced the problem of identifying bull's head watermarks, which obviously imitate the Italian bull's head watermarks but are noticeably different. ${ }^{29}$ Albeit these signs were not recorded in Polish watermark catalogues, they are evidently present on archival material. Even though it was not interlaced in the Jagiellonian ledger, a folded paper with $15^{\text {th }} / 16^{\text {th }}$-century handwriting was placed into the volume belonging to Alexander's court; its fragmentary watermark also depicts a bull's head whose design does not correlate to the contemporary Italian design but seems to be identical with the unidentified watermark examined by Dąbrowski. ${ }^{30}$

A bull's head was among the most popular watermarks; consequently, it was frequently used all over Europe. As the motifs involving a bull's head are numerous and widely used all over Europe, one can say they prove the (good) quality of paper rather than could be used to specify the papermill (i.e. the place of production). A bull's head watermark with a rod on the top of the head, ending in "W" and a crown, was also used by the papermill in Wrocław. The fact that those bull's head marks cannot be identified while other watermarks' origin is dubious points to the deficiencies of currently available catalogues and scientific literature. What also makes basic research difficult is that there are many controversies, especially concerning the establishment and first decade(s) of papermills in East-Central Europe. ${ }^{31}$

ab Ao 1471 ad Ao 1507". Warszawa 1995), both are in the Collection of Iconography and Photography of the National Museum in Warsaw.

29 J. WAŻYŃSKA, J. DĄBROwsKI: Średniowieczny śląsi rękopis kościelny..., pp. 404, 424; no. of watermarks $8,22,24,25$. Accurate measurement of the watermarks and the chain line system of the moulds is given neither in the article nor in the dissertation.

${ }^{30}$ AGAD ASK 1 No. 30. fol. 145-148. No research has been carried out on this unknown origin of the item. Dąbrowski suggested the German origin of the paper as the date of the text on the paper is 1487 .

${ }^{31}$ Such an example can be the foundation of the papermill in Wrocław. Dąbrowski states that it was established in 1475, based on a nearly 200-year-old album, whose sources cannot be checked. J. DĄBRowski: Paper Manufacture in Central and Eastern Europe..., pp. 64-65. Actually there are two drawings of this watermark, both with the year 1475, and both referring to "MS" [manuscript, but without any specification]. Tromonin's Watermark Album. A Facsimile of the Moscow 1844 Edition. With Additional Materials by S.A. Klepikov. Ed. J.S.G. Simmons. Hilversum 1965 (Monumenta Chartae Papyraceae Historiam 1llustrantia, Vol. XI), filigran no. 620 and 721. Maleczyńska, who dedicated many volumes to the history of Silesian papermaking, stated that the establishment of the mill could be around 1490. K. MALECZYŃSKA: Papiernictwo na Śląsu do końca XVI w. Wrocław 1957; K. MALECZYŃsKa: Technika wyrobu 


\section{Conclusion}

If we consider these Jagiellonian ledgers in their complexity, text and material, main and auxiliary accounts, royal and princely courts together, we can obtain more accurate knowledge from these archival sources than when simply interpreting the text. A comparison can reveal much important information for a better understanding of the use and purchase of paper in the Jagiellonian royal courts.

Scientific literature dealing with paper manufacturers of these Jagiellonianruled countries during the $15^{\text {th }}-16^{\text {th }}$ centuries emphasised historical written sources instead of systematic research on the paper of specific papermills. Based on the international literature (Briquet's and Piccard's collections), Italian products can be identified, but there is no definite location or date for those marks which are suggested to be the products of Polish mills in the literature. Unfortunately, besides the approximate location and date of existence, together with the name of an owner or papermaker, nothing is known about these mills in the first couple of years of their existence. The amount and the quality of the paper they produced as well as the sales market for their products are topics of speculation.

The quality of catalogues and watermark albums representing a segment of watermarks found on the papers in East-Central Europe is very diverse. Most of them do not correlate with the basic elements of IPH Standard. The lack of written sources and deficiency of detailed watermark research efforts to find the first paper products/watermarks of these mills have produced speculation and confusion.

Without a comprehensive, well-organised, and easily searchable database of East-Central European watermarks, the beginnings of paper producing in Central Europe will remain opaque to research.

papieru na Ślasku od XVI do XVIII w. "Zeszyty Naukowe Uniwersytetu Wrocławskiego. Historia” 1960 (Ser. A), Vol. 4, No. 29, pp. 27-49; K. MALECZyŃsKa: Dzieje starego papiernictwa ślaskiego. Wrocław 1961, p. 22. 
References

\section{Electronic sources}

Briquet Online, http://www.ksbm.oeaw.ac.at/_scripts/php/BR.php [accessed: 17 ${ }^{\text {th }}$ September 2019].

https://bernstein.oeaw.ac.at/twiki/bin/view/Main/Conference_Cork20191016.html [accessed: $29^{\text {th }}$ November 2019].

International Association of Paper Historians (IPH): International Standard for the Registration of Paper with or without Watermarks, English Version 2.0, 1997, http://www.paperhistory .org/standard.htm [accessed: $17^{\text {th }}$ September 2019].

Piccard Online, http://www.piccard-online.de/start.php [accessed: $17^{\text {th }}$ September 2019].

WIZIS - Wasserzeichen-Informationssystem. Deutsche Forschungsgemeinschaft, 2012, www .wasserzeichen-online.de [accessed: $17^{\text {th }}$ September 2019].

WZMA - Wasserzeichen des Mittelalters. Österreichische Akademie der Wissenschaften, http://www.wzma.at/ [accessed: $17^{\text {th }}$ September 2019].

Primary sources

AGAD ASK - Archiwum Główne Akt Dawnych, Archiwum Skarbu Koronnego 1 No. 2038.

Antanavičıus D., Petrauskas R.: Lietuvos didžiojo kunigaikščio Aleksandro Jogailaičio dvaro sąkaitu knygos (1494-1504). Vilnius 2007.

KozÁK P., RÁBAI K.: Mezi periferii a centrem jagellonského světa: Registrum dvořanů knižete a krále Zikmunda I. Jagellonského z let 1493-1510. Opava 2015.

KozÁK P.: Účty budinského dvora krále Vladislava II. Jagellonského (1494-1495). Praha 2019.

KozÁK P.: Účty dvora prince Zikmunda Jagellonského, vévody hlohovského a opavského, nejvyššího hejtmana Slezska a Lužic, z let (1493) 1500-1507: Kritická edice pramene. Rationes curiae Sigismundi Iagellonici, ducis Glogoviensis et Opaviensis, Silesiae et Lusatiarum summi capitanei, de annis (1493) 1500-1507: Editio critica. Praha 2014.

OSZK — Országos Széchényi Könyvtár [National Széchényi Library in Hungary] Cod. Lat. 411.

RÁBAI K.: Jagelló Zsigmond udvarának számadáskönyve (1504-1507): The Court Account Book of Sigismund Jagiellon (1504-1507). Szeged 2014. 


\section{Secondary sources}

BADECKI K.: Znaki wodne w księgach archiwum miasta Lwowa 1382-1600 r. Lwów 1928.

Bogdán I.: Vízjelek és vízjelkutatás. "Levéltári Híradó" 1956, Vol. 8.

Borsa G.: Kalauz a régi nyomtatványokhoz: A régi nyomtatványok fogalma, anyaga, mérete és terjedelme. Budapest 2003.

BRIQUeT Ch.-M.: Les filigranes: dictionnaire historique des marques du papier des leur apparition vers 1282 jusqu'en 1600. Geneva 1907.

DĄBRowski J.: Paper Manufacture in Central and Eastern Europe before the Introduction of Paper-making Machines. Łódź 2008, http://www.paperhistory.org/dabro.pdf [accessed: $17^{\text {th }}$ September 2019].

DąBrowski J., Siniarska-Czaplicka J.: Rękodzieło papiernicze. Warszawa 1991.

DıvÉку A.: Zsigmond lengyel herceg II. Ulászló udvarában. "Századok" 1914, Vol. 48.

France F.G., Tотн M.B.: Spectral Imaging for Revealing and Preserving World Cultural Heritage. In: 19th European Signal Processing Conference. Barcelona 2011.

Harris N.: Paper and Watermarks as Bibliographical Evidence. Lyon 2017.

Horogszegi Z.: Egy számadáskönyv kultúrtörténeti vonatkozásai. In: Középkortörténeti tanulmányok. Az 5. Medievisztikai PhD-konferencia (Szeged, 2007. június 7-8.) elöadásai. Ed. M. Halmágyi. Szeged 2007.

Joachima Lelewela bibljograficznych ksiag dwoje, w których rozebrane i pomnożone zostaty dwa dzieła Jerzego Samuela Bandtke: Historja drukarń krakowskich — tudzież Historja Bibljoteki Uniw. Jagiell. w Krakowie, a przydany Katalog inkunabulow polskich. Vol. 2. Wilno 1826. Tablica XVII-XVIII.

Karnaukohov V.: Methods and Tools for Watermark Digital Processing, Archiving and Dating. In: Eikonopoiia, Digital Imaging of Ancient Textual Heritage, Proceedings of the International Conference Helsinki 28-29 November 2010. Helsinki 2011.

KozÁK P.: Meals and Beverages on Prince Sigismund's Dining Table: Some Remarks on the Possibilities of Knowing the Diet of the Jagiellonian Rulers at the Turn of the $15^{\text {th }}$ and $16^{\text {th }}$ Centuries. "Perspektywy Kultury" 2016, Vol. 15.

MaleczyńsKa K.: Dzieje starego papiernictwa ślaskiego. Wrocław 1961.

MalecZyńska K.: Papiernictwo na Ślasku do końca XVI w. Wrocław 1957.

MaleCZyŃska K.: Technika wyrobu papieru na Ślasku od XVI do XVIII w. "Zeszyty Naukowe Uniwersytetu Wrocławskiego. Historia” 1960 (Ser. A), Vol. 4, No. 29.

NalewajeK A.: Na królewskim dworze Jana Olbrachta. "Roczniki Humanistyczne" 2011, Vol. 49.

Papiernie w Polsce XVI wieku: prace Franciszka Piekosińskiego, Jana Ptaśnika, Kazimierza Piekarskiego. Ed. W. BudKA. Wrocław 1971.

PtaŚnIK J.: Papiernie w Polsce XVI wieku. Kraków 1920.

RÁBAI K.: Jagelló Zsigmond számadásainak orvostörténeti tanulságai. In: Középkortörténeti tanulmányok. Az 5. Medievisztikai PhD-konferencia (Szeged, 2007. június 7-8.) elöadásai. Ed. M. HalmáGy. Szeged 2007.

RÁBAI K.: The Usage and Acquisition of Paper in the Jagiellonian Courts, 1490-1507. In: The Paper Trade in Early Modern Europe. Practices, Materials, Networks. Eds. D. BellinGRADT, A. REYNOLDS. Leiden-Boston 2021 (forthcoming).

Siniarska-Czaplicka J.: Filigrany papierni położonych na obszarze Rzeczypospolitej Polskiej od poczatku XVI do połowy XVIII wieku. Wrocław 1969.

Siniarska-CzaPlicka J.: Katalog filigranów czerpalni Rzeczypospolitej zebrany z papieru druków tłoczonych w latach 1500-1800. Łódź 1983. 
Jagellonian Ledgers as Sources for Watermark Research and Paper History Studies...

SkibNiewska J.: Dwór królewski Aleksandra Jagiellończyka w latach 1501-1506. Lublin 2015.

Tromonin's Watermark Album. A Facsimile of the Moscow 1844 Edition. With Additional Materials by S.A. Klepikov. Ed. J.S.G. Simmons. Hilversum 1965 (Monumenta Chartae Papyraceae Historiam lllustrantia, Vol. XI).

WAŻYŃSKa J., DĄBRowsKi J.: Średniowieczny śląski rękopis kościelny cennym źródtem filigranów. "Przegląd Papierniczy" 1998, Vol. 54.

WAŻYŃsKa J.: Dokumentacja konserwatorska oprawnego kodeksu rękopiśmiennego „Rationes Frumentorum Parochialis [Schweidnitzensis] ab Ao 1471 ad Ao 1507”. Warszawa 1995.

Zhang Z., Ewert U., Barret T.D., Bond L.J.: Paper Watermark Imaging Using Electron and Low Energy X-ray Radiography. "AIP Conference Proceedings" 2019, Vol. 2102, No. 1.

Żurowski S.: Znaki wodne papiernictwa wielkopolskiego XVI-XIX w. Poznań 1965.

Krisztina Rábai

Jagiellońskie księgi rachunkowe jako źródło badań nad znakami wodnymi i historią
papiernictwa - pierwsze papiernie w Europie Środkowo-Wschodniej

Streszczenie

Niniejsze studium opiera się na analizie papieru i tekstów królewskich oraz książęcych sprawozdań, w których skrybowie odnotowywali codzienne przychody i wydatki czterech dworów Jagiellonów, zlokalizowanych w różnych częściach Europy Środkowo-Wschodniej na przełomie XV i XVI wieku. Okres ten obejmuje powstanie i pierwsze lata funkcjonowania papierni na Śląsku i w Królestwie Polskim. Biorąc pod uwagę brak źródeł archiwalnych, dotyczących założenia i działalności tych papierni - kolebek papiernictwa w Europie ŚrodkowoWschodniej - trzeba wykorzystać wiele różnych, dosyć lakonicznych źródeł pisanych, aby rzucić światło na tamte rewolucyjne lata.

Chociaż sprawozdania zawierają wzmianki o zakupach, handlu i wykorzystywaniu papieru, w większości przypadków informacje zawarte w tekście nie są wystarczające do tego, aby zrekonstruować szczegółowy i jasny obraz papiernictwa — trzeba, aby naukowcy zbadali samo narzędzie wykorzystywane do pisania, jakim jest papier. Zamiast badania pojedynczych stronic papieru, użyteczne okazały się składane karty papieru, małe notesy i zszywane księgi zawierające sprawozdania. Można porównać karty z tych tomów i odnaleźć ślady prowadzące do papierni, z których one pochodzą.

Dzięki szczegółowemu badaniu jednej, szczególnie bogatej i ciekawej księgi rachunkowej z dworu księcia Zygmunta, autorka stara się wykazać możliwości, jakie daje badanie znaków wodnych. Ponadto, celem artykułu jest naświetlenie olbrzymiej luki, którą łatwo można zauważyć w dziedzinie badań znaków wodnych i historii papieru w Europie Środkowo-Wschodniej, jak również konieczności rozwoju bazy danych ze znakami wodnymi, odzwierciedlającymi historię papiernictwa $\mathrm{w}$ tym regionie.

Słowa klucze: analiza znaków wodnych, pierwsze papiernie w Europie ŚrodkowoWschodniej, handel papierem, dynastia Jagiellonów, sprawozdania królewskie 


\section{Krisztina Rabai}

Jagiellonische Rechnungsbücher als Quelle für die Forschungen über Wasserzeichen und Geschichte der Papierherstellung — die ersten Papierfabriken in Mittel- und Osteuropa

\section{Zusammenfassung}

Die vorliegende Studie basiert auf der Analyse von Papier und königlichen Texten sowie fürstlichen Berichten, in denen die Schreiber die täglichen Einnahmen und Ausgaben von vier jagiellonischen Höfen in verschiedenen Teilen Mittel- und Osteuropas um die Wende des 15. und 16. Jahrhunderts aufzeichneten. Dieser Zeitraum umfasst die Gründung und die ersten Betriebsjahre der Papierfabriken in Schlesien und im Königreich Polen. Angesichts des Mangels an Archivquellen, die die Gründung und das Funktionieren dieser Papierfabriken - Wiegen der Papierherstellung in Mittel- und Osteuropa - betreffen, müssen viele verschiedene, ziemlich lakonische schriftliche Quellen herangezogen werden, um die damaligen revolutionären Jahre zu beleuchten.

Obwohl in den Berichten von dem Kauf, dem Handel und der Verwendung von Papier die Rede ist, reichen die Informationen im Text in den meisten Fällen nicht aus, um ein detailliertes und klares Bild der Papierindustrie zu rekonstruieren. Es ist erforderlich, dass Wissenschaftler das Schreibwerkzeug selbst, das Papier, erforschen. Anstatt einzelne Papierseiten zu untersuchen, erweisen sich gefaltete Blätter, kleine Notizbücher und geheftete Bücher mit Berichten als nützlich. Es ist möglich, die Blätter aus diesen Bänden miteinander zu vergleichen und solche Spuren zu entdecken, die zu Papierfabriken führen, aus denen sie stammen.

Mit der detaillierten Analyse eines besonders reichen und interessanten Rechnungsbuchs vom Hof des Herzogs Sigismund versucht die Autorin, die Möglichkeiten aufzuzeigen, die die Untersuchung von Wasserzeichen bietet. Ziel des Beitrags ist es auch, auf die riesige Lücke zu verweisen, die im Bereich der Wasserzeichenforschung und der Papiergeschichte in Mittel- und Osteuropa leicht zu erkennen ist. Außerdem sollte die Notwendigkeit bewusst gemacht werden, eine Datenbank mit Wasserzeichen zu entwickeln, die die Geschichte der Papierherstellung in dieser Region widerspiegeln.

Schlüsselwörter: Wasserzeichenanalyse, erste Papierfabriken in Mittel- und Osteuropa, Papierhandel, Jagiellonen-Dynastie, königliche Berichte 